Sains Malaysiana 47(6)(2018): 1277-1283

http://dx.doi.org/10.17576/jsm-2018-4706-24

\title{
Analysis of Heavy Metal Accumulation in Fish at Terengganu Coastal Area, Malaysia
}

(Analisis Pengumpulan Logam Berat dalam Ikan di Kawasan Pantai Terengganu, Malaysia)

\author{
M.N.R.ROSLI*, S.B.SAMAT, M.S. YASIR \& M.F.M. YUSOF
}

\begin{abstract}
Bioaccumulation of toxic metals in fish causes serious threats to human when they are consumed. Thus, the detection of toxic element concentration levels in aquatic component is important. The accumulation of some heavy metals such as $\mathrm{Cd}, \mathrm{Cu}, \mathrm{Fe}, \mathrm{Mn}, \mathrm{Pb}$ and $\mathrm{Zn}$ in fish were determined. Ten species (Selaroides leptolepis, Decapterus maraudsi, Epinephelus lanceolatus, Priacanthus tayenus, Rastrelliger, Megalaspis cordyla, Nibea soldado, Pristipomoides filamentosus, Bramidae and Siganus canaliculatus) were collected from Terengganu coastal area, Malaysia. The analysis was done using inductive coupled plasma-mass spectrometer (ICP-MS) technique. In general, the concentration levels of heavy metals in fish samples are lower than the previous study in various locations. The highest average level of heavy metal recorded in fish is Fe followed by $\mathrm{Zn}, \mathrm{Mn}, \mathrm{Cu}, \mathrm{Cd}$ and $\mathrm{Pb}$. The metal concentration found in this study was lower than the national and international recommended dietary allowance (RDA) for human consumption except Fe $\left(52.33 \times 10^{-2} \pm 6.39 \times 10^{-2}\right.$ $m g \mathrm{~kg}^{-1}$ ) which exceeded the limit of $0.3 \mathrm{mg} \mathrm{kg}^{-1}$. Long term monitoring system of metal bioaccumulation in fishes need to be done to provide useful information for the assessment of the potential health risks of metals in Malaysia.
\end{abstract}

Keywords: Bioaccumulation; heavy metals; inductive coupled plasma-mass spectrometry (ICP-MS); Malaysia; recommended dietary allowance (RDA); Terengganu coastal area

\section{ABSTRAK}

Biotumpukan logam toksik dalam ikan akan menyebabkan ancaman serius kepada manusia apabila ia dimakan. Oleh itu, pengesanan tahap kepekatan unsur toksik dalam komponen akuatik adalah penting. Pengumpulan beberapa logam berat seperti $\mathrm{Cd}, \mathrm{Cu}, \mathrm{Fe}, \mathrm{Mn}, \mathrm{Pb}$ dan Zn dalam ikan telah ditentukan. Sepuluh spesies (Selaroides leptolepis, Decapterus maraudsi, Epinephelus lanceolatus, Priacanthus tayenus, Rastrelliger, Megalaspis cordyla, Nibea soldado, Pristipomoides filamentosus, Bramidae dan Siganus canaliculatus) dikumpulkan dari kawasan pantai Terengganu, Malaysia. Analisis dilakukan dengan menggunakan spektrometri jisim-plasma gandingan teraruh (ICP-MS). Secara amnya, tahap kepekatan logam berat dalam sampel ikan lebih rendah daripada kajian terdahulu di pelbagai lokasi. Tahap purata tertinggi logam berat yang direkodkan dalam ikan adalah $\mathrm{Fe}$ diikuti oleh $\mathrm{Zn}, \mathrm{Mn}, \mathrm{Cu}, \mathrm{Cd}$ dan $\mathrm{Pb}$. Kepekatan logam yang terdapat dalam kajian ini adalah lebih rendah daripada had pemakanan yang disyorkan (RDA) oleh badan tempatan dan antarabangsa untuk kegunaan manusia kecuali Fe $\left(52.33 \times 10^{-2} \pm 6.39 \times 10^{-2} \mathrm{mg} \mathrm{kg}^{-1}\right)$ yang melebihi had $0.3 \mathrm{mg} \mathrm{kg}^{-1}$. Sistem pengawasan jangka panjang biotumpukan logam dalam ikan perlu dijalankan untuk memberikan maklumat berguna dalam menilai potensi risiko kesihatan berkaitan logam di Malaysia.

Kata kunci: Biotumpukan; had pemakanan yang disyorkan (RDA); kawasan pantai Terengganu; logam berat; Malaysia; spektrometri jisim-plasma gandingan teraruh (ICP-MS)

\section{INTRODUCTION}

The South China Sea is one of the world's most diverse global marine bio-systems, hosting $76 \%$ of the world's coral species and $37 \%$ of reef-fish species. It possesses rich natural resources, such as fisheries, tourism, natural gas and oil reserves, which have the potential to contribute significant economic value to the neighbouring countries (Moberg \& Folke 1999). Considering the circumstance of the big increase of fishing and culturing activities in the South China Sea and fast socioeconomic developing of surrounding regions, such intensive human activities in Terengganu coast will discharge pollutants into the local environment and threaten marine organisms (Agusa et al.
2005; Zhu et al. 2014). Furthermore, the fishes captured will be consumed by the people living in the neighbouring countries and this raises concern about the potential health risks (Gu et al. 2016; Liu et al. 2015). Research regarding the concentration and source of metals in fish from the coastal waters of Terengganu is scarce.

The contamination of fresh and marine waters with wide range of pollutants has become a major concern (Dirilgen 2001; Vutukuru 2005). In recent decades, domestic, industrial and other anthropogenic activities have contributed to the increase of heavy metal contamination in the water and have directly influenced aquatic ecosystem (Kaur 2008; Velez \& Montoro 1998). Pollutants deposited 
into the water causes serious changes, which in turn directly or indirectly affect the ecological balance of the environment, creating extensive damage and even mass mortality to the life and activities of aquatic organisms because of their high toxicity and accumulative behaviour (Matta et al. 1999). The heavy metals may reach a toxic concentration level that can potentially damage the ecological environment (Agusa et al. 2007, 2005; Hajeb et al. 2009). The natural concentrations of these metals in sea water are very low and the risk of contamination in living tissue is high, when the organisms started accumulating more amounts of metals than the level of excretion (Kamaruzaman et al. 2011).

Fish are aquatic organisms among the most studied content of heavy metals because fishes are good indicators of heavy metal contamination in aquatic systems because they occupy different tropic levels and are of different sizes and ages (Burger et al. 2002). The varying levels of heavy metals in different fish species could be the result of ecological needs, metabolism and feeding patterns and behaviour and body size (Tuzen 2003; Yilmaz 2003). The deposition of the heavy metals has increased the uptake rate by aquatic organisms, such as fishes, consequently affecting humans through the food web (Dimari et al. 2008; Ganbi 2010). The intake rate of these heavy metals by humans through the consumption of fish causes serious health hazards (Luoma \& Rainbow 2008; Puel et al. 1987). The entry of heavy metals into the body's system of living organisms is usually influenced by the body's balance of homeostasis. However, if a concentration range of the metal exceeds the limit load of body, the process of homeostasis can no longer function and ultimately resulting in toxic effects to the body either acute or chronic (Forstner \& Wittmann 1979). For instance, metals such as $\mathrm{Cu}$ and $\mathrm{Zn}$ are essential for fish metabolism whereas others, such as $\mathrm{Cd}$, have no established role in biological systems (Canli \& Atli 2003). The previous studies have shown that heavy metals may alter the physiological activities and biochemical parameters both in tissues and in blood (Basha \& Rani 2003).

Fisheries are one of the most important food production sectors in supplying protein to the human in the world. According to the Food and Agriculture Organisation (FAO), the increasing health consciousness of the consumers making the fish demands increase drastically during the past decade. Considering these issues, present research was initiated to determine the bioaccumulation level of heavy metals in some commercially important fishes from Terengganu coastal area of Malaysia.

\section{MATERIALS AND METHODS}

\section{SAMPLE AND SAMPLING LOCATION}

The sample of the fish species were obtained from three fishing locations in Terengganu coastal area, Malaysia as shown in Figure 1. These locations were identified as the regular fishing areas to cater for the food supplies in the state of Terengganu and Pahang. These fish were caught using a typical fisherman's trawl. Fish samples studied are Selaroides leptolepis, Decapterus maraudsi, Epinephelus lanceolatus, Priacanthus tayenus, Rastrelliger, Megalaspis cordyla, Nibea soldado, Pristipomoides filamentosus, Bramidae and Siganus canaliculatus.

\section{SAMPLES TREATMENT}

The fish were washed using distilled water to remove the residual sea water and the head, viscera, gills and flesh were separated. The fish samples were dried in an oven $105^{\circ} \mathrm{C}$ until the weight becomes constant. The dry weights of the fishes were measured by calculating the different between the wet and the weight after oven drying. The fish samples are milled to obtain a fine grain of about $500 \mu \mathrm{m}$ sizes. A total of $0.1 \mathrm{~g}$ fish samples are then mixed with 4.0 and 6.0 $\mathrm{mL}$ of nitric acid and hydrochloric acid. The samples are then digested using a microwave oven for 55 min until the solution is clear. The resulting solutions are then filtered and distilled water is added until the volumes of the sample solution are $100 \mathrm{~mL}$ (Yasir et al. 2008).

\section{SAMPLES ANALYSIS}

Samples that were prepared in the form of a solution were analyzed using an inductive coupled plasma-mass spectrometry (ICP-MS) has been calibrated using the standard (SRM MA-A-2 (TM) Fish Flesh Homogenate) (Yasir et al. 2008). The values of the heavy metal concentrations in the tissues were calculated based on dry weights as this discounts the variability due to inner parts differences in the moisture content of organisms. A blank in replicates were used to control the accurateness of this procedure.

\section{RESULTS AND DISCUSSION}

Table 1 shows that $\mathrm{Fe}$ concentration is the highest in average followed by $\mathrm{Zn}, \mathrm{Mn}, \mathrm{Cu}, \mathrm{Cd}$ and $\mathrm{Pb} . \mathrm{Cu}, \mathrm{Fe}, \mathrm{Mn}$ and $\mathrm{Zn}$ are classified as essential trace elements and $\mathrm{Cd}$ and $\mathrm{Pb}$ are toxic trace elements. Essential metals $(\mathrm{Cu}, \mathrm{Fe}$, $\mathrm{Mn}$ and $\mathrm{Zn}$ ) are carefully regulated by the physiological mechanisms in most organisms and they played crucial role as precursors in most of the enzymatic activities (Kamaruzaman et al. 2011). Thus, the knowledge of their concentrations in fish is important in terms of their management and for human consumption. Accumulation of metal in different species is the function of their respective membrane permeability and enzyme system which is highly species specifics (Lakshmanan et al. 2009). Thus, different metals accumulated in different orders in different fish samples.

Megalaspis cordyla accumulated higher amount of $\mathrm{Fe}\left(66.72 \times 10^{-2} \pm 22.13 \times 10^{-2} \mathrm{mg} \mathrm{kg}^{-1}\right)$ followed by Rastrelliger $\left(66.15 \times 10^{-2} \pm 18.25 \times 10^{-2} \mathrm{mg} \mathrm{kg}^{-1}\right)$. Meanwhile, the lowest concentration of Fe was detected in Nibea soldado $\left(40.36 \times 10^{-2} \pm 19.13 \times 10^{-2} \mathrm{mg} \mathrm{kg}^{-1}\right)$ followed by Priacanthus tayenus $\left(39.95 \times 10^{-2} \pm 24.14 \times\right.$ $\left.10^{-2} \mathrm{mg} \mathrm{kg}^{-1}\right)$. In comparison with previous reported study 


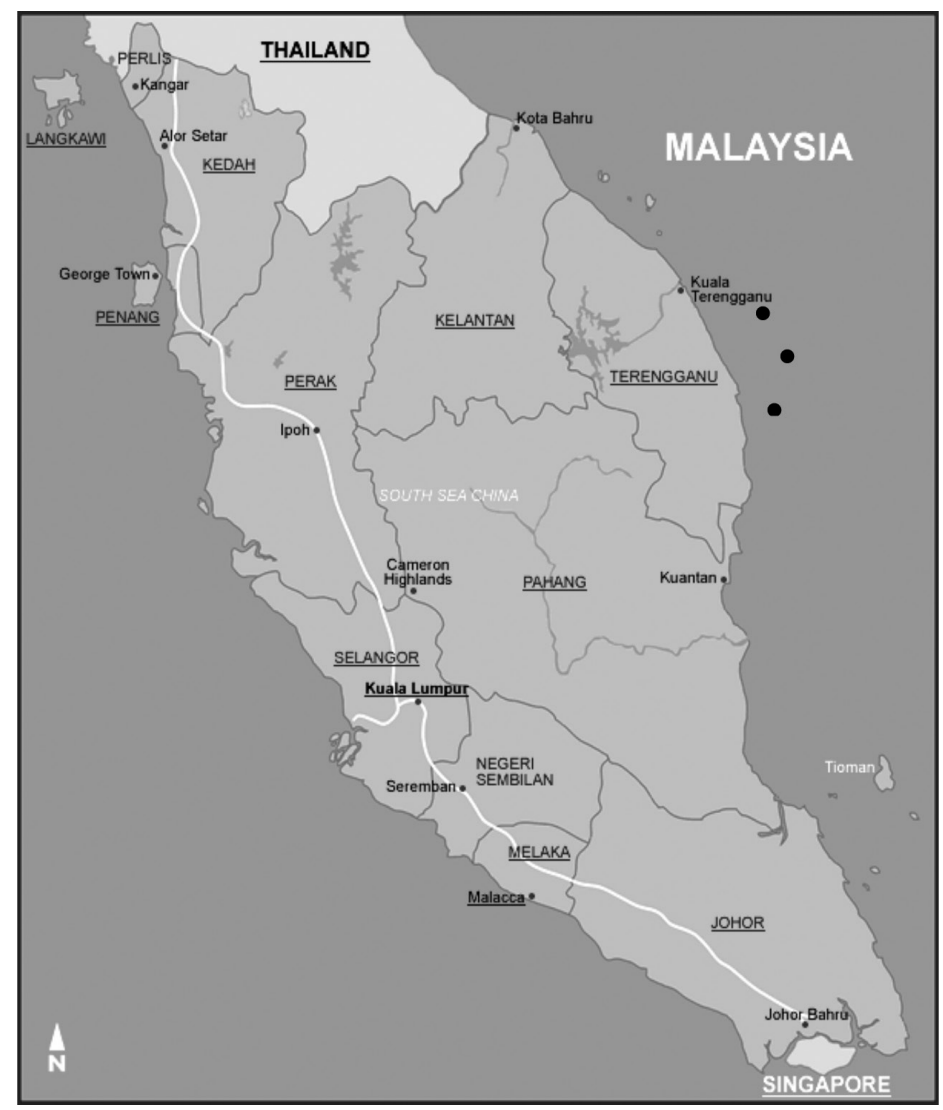

FIGURE 1. Map showing the study areas. Black circles $(\bullet)$ denote the sampling site

TABLE 1 . Heavy metal concentration in samples

\begin{tabular}{lcccccc}
\hline \multirow{2}{*}{ Species } & \multicolumn{5}{c}{ Heavy metal concentration in samples $\left(\mathrm{mg} \mathrm{kg}^{-1}\right)\left(\times 10^{-2}\right)$} \\
\cline { 2 - 7 } & $\mathrm{Cd}$ & $\mathrm{Cu}$ & $\mathrm{Fe}$ & $\mathrm{Mn}$ & $\mathrm{Pb}$ & $\mathrm{Zn}$ \\
\hline Decapterus maraudsi & $0.20 \pm 0.03$ & $0.64 \pm 0.44$ & $42.92 \pm 15.35$ & $0.68 \pm 0.34$ & $0.17 \pm 0.12$ & $7.97 \pm 2.57$ \\
Megalaspis cordyla & $0.31 \pm 0.31$ & $1.16 \pm 0.50$ & $66.72 \pm 22.13$ & $1.36 \pm 0.71$ & $0.02 \pm 0.02$ & $10.42 \pm 3.07$ \\
Bramidae & $1.53 \pm 0.42$ & $0.98 \pm 0.24$ & $62.73 \pm 28.56$ & $4.05 \pm 3.00$ & $0.09 \pm 0.03$ & $15.14 \pm 3.10$ \\
Selaroides leptolepis & $0.66 \pm 0.10$ & $0.68 \pm 0.39$ & $61.05 \pm 15.65$ & $0.87 \pm 0.29$ & $0.14 \pm 0.02$ & $11.28 \pm 2.28$ \\
Epinephelus lanceolatus & $0.64 \pm 0.31$ & $0.83 \pm 0.67$ & $40.92 \pm 15.82$ & $0.88 \pm 0.39$ & $0.11 \pm 0.06$ & $12.51 \pm 4.54$ \\
Rastrelliger & $0.25 \pm 0.15$ & $0.57 \pm 0.23$ & $66.15 \pm 18.25$ & $1.74 \pm 0.87$ & $0.73 \pm 0.06$ & $9.39 \pm 1.56$ \\
Nibea soldado & $0.12 \pm 0.07$ & $0.21 \pm 0.10$ & $40.36 \pm 19.13$ & $1.97 \pm 1.00$ & $\mathrm{ND}$ & $5.91 \pm 2.38$ \\
Pristipomoides filamentosus & $0.08 \pm 0.07$ & $0.25 \pm 0.12$ & $52.61 \pm 22.77$ & $1.47 \pm 0.92$ & $\mathrm{ND}$ & $4.88 \pm 2.12$ \\
Priacanthus tayenus & $0.08 \pm 0.04$ & $0.42 \pm 0.18$ & $39.95 \pm 24.14$ & $1.20 \pm 0.55$ & $0.13 \pm 0.11$ & $6.63 \pm 2.42$ \\
Siganus canaliculatus & $0.10 \pm 0.07$ & $0.68 \pm 0.28$ & $49.90 \pm 22.90$ & $1.20 \pm 0.55$ & $0.15 \pm 0.15$ & $11.60 \pm 2.28$ \\
Average & $0.39 \pm 0.26$ & $0.64 \pm 0.17$ & $52.33 \pm 6.39$ & $1.54 \pm 0.56$ & $0.19 \pm 0.13$ & $9.57 \pm 1.87$ \\
MFAR* & 100 & 3000 & 30 & $\mathrm{NP}$ & 200 & 10000 \\
FAO/WHO** & 20 & 1000 & 30 & 540 & 100 & 15000 \\
\hline
\end{tabular}

ND means not detected in fish species

* Malaysian Food Act and Regulation (MFAR 1985) / NP means no permissible limits in MFAR / FAO/WHO (1984

in Brazil and Bulgaria, the average concentration of $\mathrm{Fe}$ in present study $\left(52.33 \times 10^{-2} \pm 6.39 \times 10^{-2} \mathrm{mg} \mathrm{kg}^{-1}\right)$ is the lowest as shown in Table 2. Iron comes in several forms in water. It can be dissolved in the water or so heavy that it forms precipitate or microscopic solid pieces suspended in the water. The recommended dietary allowance (RDA) by FAO/WHO (1984) for adults is $0.3 \mathrm{mg} \mathrm{kg}^{-1}$ and FSA (UK Total Diet Study 2008) recommended less than $12 \mathrm{mg} \mathrm{day}^{-1}$. However, the average of $\mathrm{Fe}$ in this study $\left(52.33 \times 10^{-2}\right.$ $\mathrm{mg} \mathrm{kg}^{-1}$ ) was higher than recommended level in Malaysia 
TABLE 2. Comparison with previous studies $\left(\mathrm{mg} \mathrm{kg}^{-1}\right)$

\begin{tabular}{ccccccc}
\hline & \multicolumn{5}{c}{ Comparison } \\
\cline { 2 - 7 } Logam & $\begin{array}{c}\text { Present Study } \\
\left(\times 10^{-2}\right)\end{array}$ & $\begin{array}{c}\text { Kapar, Malaysia } \\
\text { (Bashir et al. } \\
2013)\end{array}$ & $\begin{array}{c}\text { Mersing, Malaysia } \\
\text { (Bashir et al. } \\
2013)\end{array}$ & $\begin{array}{c}\text { IAEA-407 } \\
\text { (Wyse et al. } \\
2003)\end{array}$ & $\begin{array}{c}\text { Bulgaria } \\
\text { (Stancheva et al. } \\
2013)\end{array}$ & $\begin{array}{c}\text { Brazil } \\
\text { (Renata et al. } \\
2012)\end{array}$ \\
\hline $\mathrm{Cd}$ & $0.39 \pm 0.14$ & $0.19 \pm 0.09$ & $2.34 \pm 2.20$ & 0.18 & $0.005-0.01$ & $0.001-0.09$ \\
$\mathrm{Cu}$ & $0.63 \pm 0.10$ & $7.85 \pm 5.23$ & $12.91 \pm 8.80$ & - & $0.34-1.40$ & $1.20-2.90$ \\
$\mathrm{Fe}$ & $52.30 \pm 3.51$ & - & - & 146 & $2.2-9.0$ & $1.60-7.50$ \\
$\mathrm{Mn}$ & $1.53 \pm 0.31$ & $19.41 \pm 12.32$ & $9.67 \pm 4.34$ & - & $0.06-0.17$ & $0.30-1.70$ \\
$\mathrm{~Pb}$ & $0.08 \pm 0.02$ & - & - & 0.12 & $0.03-0.08$ & $0.004-0.3$ \\
$\mathrm{Zn}$ & $9.57 \pm 1.02$ & $158.76 \pm 79.65$ & $217.37 \pm 120.91$ & - & $5.2-11.0$ & $2.70-9.30$ \\
\hline
\end{tabular}

$0.3 \mathrm{mg} \mathrm{kg}^{-1}$ by Malaysian Food Act and Regulations (1985). According to Finch and Huebers (1982), the higher accumulation of $\mathrm{Fe}$ in the living organisms is a normal situation. However, Fe strives to be toxic to humans if it exceeds $200 \mathrm{mg} \mathrm{kg}^{-1}$. It was reported that Iron deficiency is frequently associated with anaemia and thus, with reduced working capacity and impaired intellectual development.

$\mathrm{Zn}$ is critical for aquatic organisms, including fishes; however, $\mathrm{Zn}$ becomes poisonous when it exceeds its maximum value. The high $\mathrm{Zn}$ concentrations in fishes in this study might also because $\mathrm{Zn}$ is necessary element for embryo development and important to reproductive organs (El-sharif et al. 2009). In human nutrition, Zinc is an important trace element and fulfils many biochemical functions in human metabolism. A Zn deficiency in human organism leads to several disorders, but an excessive $\mathrm{Zn}$ intake can cause acute adverse effects (Scherz \& Kirchhoff 2006). Epinephelus lanceolatus accumulated higher amount of $\mathrm{Zn}\left(12.51 \times 10^{-2} \pm 4.54 \times 10^{-2} \mathrm{mg} \mathrm{kg}^{-1}\right)$ followed by Bramidae $\left(15.14 \times 10^{-2} \pm 3.10 \times 10^{-2} \mathrm{mg} \mathrm{kg}^{-1}\right.$. Meanwhile, the lowest concentration of $\mathrm{Zn}$ was detected in Nibea soldado $\left(5.91 \times 10^{-2} \pm 2.38 \times 10^{-2} \mathrm{mg} \mathrm{kg}^{-1}\right)$ followed by Priacanthus tayenus $\left(4.88 \times 10^{-2} \pm 2.12 \times 10^{-2}\right.$ $\left.\mathrm{mg} \mathrm{kg}^{-1}\right)$. The average $\mathrm{Zn}$ level $\left(9.57 \times 10^{-2} \pm 1.87 \times 10^{-2}\right.$ $\mathrm{mg} \mathrm{kg}^{-1}$ ) are lower than level established by Malaysian Food Act and Regulations (1985); recommended Zn level established for fish is $100 \mathrm{mg} \mathrm{kg}^{-1}$. Meanwhile, FAO/WHO (1984) recommended dietary allowance of $\mathrm{Zn}$ for adults is $150 \mathrm{mg} \mathrm{kg}^{-1}$. The average $\mathrm{Zn}$ concentrations level in present study are the lowest in comparisons with previous reported levels in multi-species marine fishes as shown in Table 2 (Bashir et al. 2013; Renata et al. 2012; Stancheva 2013). Industrial wastewaters containing zinc stem from galvanic industries, battery production and others might lead to higher amount of zinc in the seawater.

Manganese is an essential element for both animals and plants and Mn deficiency results in severe skeletal and reproductive abnormalities in mammals (Sivaperumal et al. 2007). Rastrelliger accumulated higher amount of Mn $\left(1.74 \times 10^{-2} \pm 0.87 \times 10^{-2} \mathrm{mg} \mathrm{kg}^{-1}\right)$ followed by Nibea soldado $\left(1.97 \times 10^{-2} \pm 1.00 \times 10^{-2} \mathrm{mg} \mathrm{kg}^{-1}\right)$. Meanwhile, the lowest concentration of Mn was detected in Selaroides leptolepis $\left(0.87 \times 10^{-2} \pm 0.29 \times 10^{-2} \mathrm{mg} \mathrm{kg}^{-1}\right)$ followed by
Decapterus maraudsi $\left(0.68 \times 10^{-2} \pm 0.34 \times 10^{-2} \mathrm{mg} \mathrm{kg}^{-1}\right)$. Although high concentrations of Mn may have toxic effects for human beings, no formal RDA in Malaysia has been established. However, NAS (1989) recommended adequate intake for $\mathrm{Mn}$ is 2.3 and $1.8 \mathrm{mg} \mathrm{day}^{-1}$ for adult men and women, respectively. Meanwhile, FAO/WHO (1984) permissible limits of Mn are $5.4 \mathrm{mg} \mathrm{kg}^{-1}$. The average Mn concentrations level $\left(1.53 \times 10^{-2} \pm 0.31 \times\right.$ $\left.10^{-2} \mathrm{mg} \mathrm{kg}^{-1}\right)$ were lower than those reported in Kapar $\left(19.41 \pm 12.32 \mathrm{mg} \mathrm{kg}^{-1}\right)$ and Mersing $(9.67 \pm 4.34 \mathrm{mg}$ $\mathrm{kg}^{-1}$ ) (Bashir et al. 2013).

Copper is an essential element that is carefully regulated by physiological mechanisms in most organisms (Erdogrul \& Ates 2006). Cu can be found in a natural environment and is essential for the normal growth and metabolism of all living organisms (Eisler 1998). However, it can pose potential hazards that endanger both animal and human health because copper becomes toxic at high concentrations. Bramidae accumulated higher amount of $\mathrm{Cu}\left(0.98 \times 10^{-2} \pm 0.24 \times 10^{-2} \mathrm{mg} \mathrm{kg}^{-1}\right)$ followed by Megalaspis cordyla $\left(1.16 \times 10^{-2} \pm 0.50 \times 10^{-2}\right.$ $\left.\mathrm{mg} \mathrm{kg}^{-1}\right)$. Meanwhile, the lowest concentration of $\mathrm{Cu}$ was detected in Pristipomoides filamentosus $\left(0.25 \times 10^{-2} \pm\right.$ $\left.0.12 \times 10^{-2} \mathrm{mg} \mathrm{kg}^{-1}\right)$ followed by Nibae soldado $(0.21 \times$ $\left.10^{-2} \pm 0.10 \times 10^{-2} \mathrm{mg} \mathrm{kg}^{-1}\right)$. The average $\mathrm{Cu}$ concentrations reported in the present study $\left(0.64 \times 10^{-2} \pm 0.17 \times 10^{-2}\right.$ $\left.\mathrm{mg} \mathrm{kg}^{-1}\right)$ are generally lower than Kapar $(7.85 \pm 5.23 \mathrm{mg}$ $\left.\mathrm{kg}^{-1}\right)$ and Mersing $\left(12.91 \pm 8.80 \mathrm{mg} \mathrm{kg}^{-1}\right)$. The proposed permissible daily dose of $\mathrm{Cu}$ for adults is $0.05 \mathrm{mg} \mathrm{kg}^{-1}$ for a man with a body weight of $70 \mathrm{~kg}$ (NAS 1989). Meanwhile, Malaysian Food Act and Regulation (1985) recommended dietary allowance of $30 \mathrm{mg} \mathrm{kg}^{-1}$ and FAO/ WHO (1984) recommended $10 \mathrm{mg} \mathrm{kg}^{-1}$ for $\mathrm{Cu}$ intake.

Cadmium is a toxic element that could be present in fish organism at high concentrations (Turkmen et al. 2009). An important distribution route is the circulatory system whereas blood vessels are considered to be main stream organs of cadmium toxicity. Chronic exposure to cadmium particulates is generally associated with changes in pulmonary function and chest radiographs that consistent with emphysema (Davison et al. 1988). The maximum Cd level for fish established by the Malaysian Food Act and Regulation (1985) is $1.0 \mathrm{mg} \mathrm{kg}^{-1}$. Selaroides leptolepis accumulated higher amount of $\mathrm{Cd}\left(0.66 \times 10^{-2} \pm\right.$ 
$\left.0.10 \times 10^{-2} \mathrm{mg} \mathrm{kg}^{-1}\right)$ followed by Bramidae $\left(1.53 \times 10^{-2} \pm\right.$ $\left.0.42 \times 10^{-2} \mathrm{mg} \mathrm{kg}^{-1}\right)$. Meanwhile, the lowest concentration of Cd was detected in Pristipomoides filamentosus $(0.08$ $\left.\times 10^{-2} \pm 0.07 \times 10^{-2} \mathrm{mg} \mathrm{kg}^{-1}\right)$ followed by Priacanthus tayenus $\left(0.08 \times 10^{-2} \pm 0.04 \times 10^{-2} \mathrm{mg} \mathrm{kg}^{-1}\right)$. However, the average $\mathrm{Cd}$ concentrations from this study; $0.39 \times 10^{-2} \pm$ $0.26 \times 10^{-2} \mathrm{mg} \mathrm{kg}^{-1}$ are generally lower than the values reported in previous studies as shown in Table 2 (Bashir et al. 2013; Renata et al. 2012; Stancheva 2013; Wyse et al. 2003). Comparison with worldwide RDA also showed that the level of $\mathrm{Cd}$ in this study is generally low (FAO/ WHO 1984; USFDA 1993).

Lead is a cumulative toxin and one of environmental contaminants which can promote serious damage to human health by damaging blood circulation, central nervous system, liver and kidneys (Ekong et al. 2006). Decapterus maraudsi accumulated higher amount of $\mathrm{Pb}$ $\left(0.17 \times 10^{-2} \pm 0.12 \times 10^{-2} \mathrm{mg} \mathrm{kg}^{-1}\right)$ followed by Rastrelliger $\left(0.73 \times 10^{-2} \pm 0.06 \times 10^{-2} \mathrm{mg} \mathrm{kg}^{-1}\right)$. Meanwhile, the lowest concentration of $\mathrm{Pb}$ was detected in Branidae (0.09 $\left.\times 10^{-2} \pm 0.03 \times 10^{-2} \mathrm{mg} \mathrm{kg}^{-1}\right)$ followed by Megalaspis cordyla $\left(0.02 \times 10^{-2} \pm 0.02 \times 10^{-2} \mathrm{mg} \mathrm{kg}^{-1}\right)$. However, $\mathrm{Pb}$ was not detected in Nibae soldado and Pristipomoides filamentosus due to limitation of the technique used. Comparison with worldwide RDA showed that the level of $\mathrm{Pb}$ in fish in this study is low and safe for consumption (FAO/WHO 1984; FSA 2008). Malaysian Food Act and Regulation (1985) established the maximum $\mathrm{Pb}$ level of $2 \mathrm{mg} \mathrm{kg}^{-1}$ and the present study shows the average of $\mathrm{Pb}$ levels in fish are lower $\left(0.19 \times 10^{-2} \pm 0.13 \times 10^{-2} \mathrm{mg} \mathrm{kg}^{-1}\right)$. In comparisons with previous research conducted in different part of the world, the average of $\mathrm{Pb}$ concentration in present study is the lowest as shown in Table 2. Even though the bioavailability of $\mathrm{Pb}$ in marine is low, their constant accumulation by aquatic organisms would cause serious threats to human health when they are consumed. Hence, knowledge on $\mathrm{Pb}$ accumulation is important for the utilization of fishes for safer human consumption.

The highest average level of heavy metal recorded in fish is Fe followed by $\mathrm{Zn}, \mathrm{Mn}, \mathrm{Cu}, \mathrm{Cd}$ and $\mathrm{Pb}$. The mean concentrations of heavy metals studied except Fe were lower than the maximum permitted concentrations recommended by FAO/WHO (1984) and Malaysian Food Act and Regulations (1985). High amounts of Fe exist in water are usually due to pollution related to iron mining, shipping route and oil rig. Over the past two decades, there have been documented instances of Chinese fishermen in the Spratly Islands and surrounding waters indulging in large-scale illegal capture of fish using cyanide, dynamite and detonating cords. The present study indicates that there are trends of higher Fe concentrations in fishes. These results indicated that some source of heavy metals contamination is present in Terengganu coastal area, Malaysia. Therefore, the long term monitoring system of metal bioaccumulation in fishes should be done to provide useful information for the assessment of the potential health risks of metals in Malaysia.

\section{CONCLUSION}

Knowledge of heavy metal concentrations in fishes is important in order to regulate the consumption of fish. The highest average level of heavy metal recorded in fish is $\mathrm{Fe}$ followed by $\mathrm{Zn}, \mathrm{Mn}, \mathrm{Cu}, \mathrm{Cd}$ and $\mathrm{Pb}$. Present study clearly showed the lower toxicity of various metal concentrations in fish from Terengganu coastal area, Malaysia. Hence, the fishes caught from Terengganu coastal area, Malaysia would not cause acute toxicity in human when it is consumed. However, the long term monitoring system of metal bioaccumulation in fishes would be important and provide useful information for the assessment of the potential health risks of metals in Malaysia.

\section{ACKNOWLEDGEMENTS}

Author expresses their sincere gratitude to the Ministry of Education Malaysia (KPM), Malaysia for the financial support, Universiti Kebangsaan Malaysia and Malaysian Fisheries Development Board (LKIM) for providing infrastructure facilities.

\section{REFERENCES}

Agusa, T., Kunita, A., Sudaryanto, T., Monirith, S.K., Klap, A. \& Iwata, H. 2007. Exposure assessment for trace elements from consumption of marine fish in Southeast Asia. Environmental Pollution 145: 266-277.

Agusa, T., Kunito, T., Yasunaga, G., Iwata, H., Subramanian, A., Ismail, A. \& Tnabe, S. 2005. Concentrations of trace elements in marine fish and its risk assessment in Malaysia. Marine Pollution Bulletin 51: 896-911.

Basha, P.S. \& Rani, A.U. 2003. Cadmium induced antioxidant defense mechanism in freshwater teleost Oreochromis mossambicus (Tilapia). Ecotoxicology and Environmental Safety 56: 218-221.

Bashir, F.H., Othman, M.S., Mazlan, A.G., Rahim, S.M. \& Simon, K.D. 2013. Heavy metal concentration in fishes from the coastal waters of Kapar and Mersing, Malaysia. Turkish Journal of Fisheries and Aquatic Sciences 13: 375-382.

Burger, J., Gaines, K.F., Shane Boring, C., Stephens, W.L., Snodgrass, J. \& Dixon, C. 2002. Metal levels in fish from the Savannah River: Potential hazards to fish and other receptors. Environmental Research 89: 85-97.

Canli, M. \& Atli, G. 2003. The relationships between heavy metal $(\mathrm{Cd}, \mathrm{Cr}, \mathrm{Cu}, \mathrm{Fe}, \mathrm{Pb}$ and $\mathrm{Zn})$ levels and the size of six Mediterranean fish species. Environment Pollution 121: 129-136.

Dimari, G.A., Abdulkarim, F.I., Akan, J.C. \& Garba, S.T. 2008. Metal concentrations in tissues of Tilapia galier, Clarias lazera, and Osteoglosidae caught from Ala Dam, Maiduguri, Borno State, Nigeria. American Journal of Environmental Sciences 4(4): 473-479.

Davison, A.G., Fayers, P.M., Taylor, A.J., Venables, K.M., Darbyshire, J. \& Pickering, C.A. 1988. Cadmium fume inhalation and emphysema. The Lancet 1(8587): 663-667.

Dirilgen, N. 2001. Accumulation of heavy metals in freshwater organisms: Assessment of toxic interactions. Turkish Journal of Chemistry 25: 173-179.

Eisler, R. 1998. Copper hazards to fish, wildlife and invertebrates: A synoptic review. Biological Science Report 33: 100-109. 
Ekong, E.B., Jaar, B.G. \& Weaver, V.M. 2006. Lead-related nephrotoxicity: A review of the epidemiological evidence. Kidney International 70: 2074-2084.

El-sherif, M.S., Ahmed, M.T., El-Danasoury, M.A. \& El-Nwishy, N.H.K. 2009. Effects of pollutants on some aquatic organisms in Temsah Lake in Egypt. Journal of Fisheries and Aquatic Sciences 4: 150-160.

Erdoĝrul, Z. \& Ates, D.A. 2006. Determination of cadmium and copper in fish samples from Sir and Menzelet dam lake Kahramanmaras, Turkey. Environmental Monitoring Assessment 117: 281-290.

FAO/WHO. 1984. List of Maximum Levels Recommended for Contaminants by the Joint FAO/WHO Codex Alimentarius Commission. Second Series. CAC/FAL, 1-8. Rome: Food and Agriculture Organization of the United Nations.

Finch, C.A. \& Huebers, H.A. 1982. Perspective in iron metabolism. National English Journal of Medicine 306: 1520-1528.

Forstner, U. \& Wittmann GTW. 1979. Metal Pollution in Aquatic Environment. Berlin: Springer-Verlag.

FSA. 2008. Total Diet Study of Metals and Other Elements. Committee on Toxicity of Chemicals in Food, Consumer Products and the Environment. tox/2008/29, December. United Kingdom.

Ganbi, H.A.A. 2010. Heavy metals pollution level in marine Hammour fish and the effect of popular cooking methods and freezing process on these pollutants. World Journal of Daily Food Sciences 5(2): 119-127.

Gu, Y.G., Lin, Q., Huang, H.H., Wang, L.G., Ning, J.J. \& Du, F.Y. 2016. Heavy metals in fish tissues/stomach contents in four marine wild commercially valuable fish species from the western continental shelf of South China Sea. Marine Pollution Bulletin 114(2): 1125-1129.

Hajeb, P., Jinap, S., Ismail, A., Fatimah, A.B., Jamilah, J. \& Rahim, M.A. 2009. Assessment of mercury level in commonly consumed marine fishes in Malaysia. Food Control 20(1): 79-84.

Kamaruzzaman, B.Y., Rina, Z., Akbar John, B. \& Jalal, K.C.A. 2011. Heavy metal accumulation in commercially important fishes of South West Malaysian coast. Research Journal of Environmental Sciences 5: 595-602.

Kaur, M., Sharma, J.K., Gill, J.P., Aulakh, R.S., Bedi, J.S. \& Joia, B.S. 2008. Determination of organochlorine pesticide residue in freshwater fish species in Punjab, India. Bulletin Environmental Contamination Toxicology 80: 154-157.

Lakshmanan, R., Kesavan, K., Vijaya, P., Rajaram, V. \& Rajagopal, S. 2009. Heavy metals accumulation in five commercially important fishes of parangipettai, southeast coast of India. Advance Journal of Food Sciences and Technology 1: 63-65.

Liu, J.L., Xu, X.R. \& Ding, Z.H. 2015. Heavy metals in wild marine fish from South China Sea: Levels, tissue and species-specific accumulation and potential risk to humans. Ecotoxicology 24: 1583-1592.

Luoma, S.N. \& Rainbow, P.R. 2008. Metal Concentration in Aquatic Environment: Science and Lateral Management. Cambridge: Cambridge University Press. 7: 129-141.

Malaysian Food Act and Regulations. 1985. Malaysian Law on Food and Drugs. Kuala Lumpur: Malaysia Law Publisher.

Matta, J., Miled, M., Manger, R. \& Tosteson, T. 1999. Heavy metals, lipid peroxidation and cigatcratoxicity in the liver of the Carbben barracula (Sphyrrena barracuba). Biological Trace Element Research 70: 69-70.
Moberg, F. \& Folke, C. 1999. Ecological goods and services of coral reef ecosystems. Ecological Economics 29: 215-233.

NAS. 1989. Recommended Dietary Allowances. Subcommittee on the Tenth Edition of the RDAs. National Academy Press

Puel, D., Zsueager, N. \& Breittmayer, N.P. 1987. Statistical assessment of a sampling pattern for evaluation of changes in $\mathrm{Hg}$ and $\mathrm{Zn}$ concentration in Patellacoerulea. Bulletin Environmental Contamination Toxicology 38: 700-706.

Renata, J.M., Lisia Maria, G.D.S. \& Aline, S.F. 2012. Determination of inorganic trace elements in edible marine fish from Rio de Janeiro State, Brazil. Food Control 23: 535-541.

Scherz, H. \& Kirchhoff, E. 2006. Trace elements in foods: Zinc contents of raw foods - a comparison of data originating from different geographical regions of the world. Journal of Food Composition and Analysis 19: 420-433.

Sivaperumal, P., Sankar, T.V. \& Nair, P.G.V. 2007. Heavy metal concentrations in fish, shellfish and fish products from internal markets of India vis-à-vis international standards. Food Chemistry 102: 612-620.

Stancheva, M., Makedonski, L. \& Peycheva, K. 2013. Determination of heavy metal concentrations of most consumed fish species from Bulgarian Black Sea Coast. Bulgarian Chemical Communications 46: 195-203.

Türkmen, M., Türkmen, A., Tepe, Y., Töre, Y. \& Ates, A. 2009. Determination of metals in fish species from Aegean and Mediterranean Seas. Food Chemistry 113: 233-237.

Tüzen, M. 2003. Determination of heavy metals in fish samples of the middle Black Sea (Turkey) by graphite furnace atomic absorption spectrometry. Food Chemistry 80(1): 119-123.

USFDA. 1993. Guidance Document of Chromium, Arsenic and Nickel in Shellfish. Washington, DC: Center for Food Safety and Applied Nutrition.

Velez,D .\& Montoro, R. 1988. Arsenic speciation in manufactured seafood products: A review. Journal of Food Protection 61: 1240-1245.

Vutukuru, S.S. 2005. Acute effects of hexavalent chromium on survival, oxygen consumption, haematological parameters and some biochemical profiles of the Indian major carp, Labeo rohita. International Journal of Environmental Research Public Health 2: 456-462.

Wyse, E.J.,Azemard, S. \& Mora, S.J. 2003. Report on the worldwide intercomparison exercise for the determination of trace elements and methylmercury in fish homogenate IAEA-404. IAEA Marine Environment Laboratory.

Yasir, M.S., Abd Majid, A., Ahmad Kabir, N. \& Yahya, R. 2008. Kandungan logam berat dan radionuklid tabii dalam ikan, air, tumbuhan dan sedimen di bekas tapak lombong. The Malaysian Journal of Analytical Sciences 12(1): 172-178.

Yilmaz,A.B. 2003. Levels of heavy metals $(\mathrm{Fe}, \mathrm{Cu}, \mathrm{Ni}, \mathrm{Cr}, \mathrm{Pb}$ and $\mathrm{Zn}$ ) in tissue of Mugil cephalus and Trachurus mediterraneus from Iskenderun Bay. Turkish Environmental Research 92: 277-281.

Zhu, C.Q., Qin, Y., Meng, Q.S., Wang, X.Z. \& Wang, R. 2014. Formation and sedimentary evolution characteristics of Yongshu Atoll in the South China Sea Islands. Ocean Engineering 84: 61-66.

M.N.R. Rosli*, S.B. Samat \& M.S. Yasir

School of Applied Physics

Faculty of Science and Technology

Universiti Kebangsaan Malaysia 
43600 UKM Bangi, Selangor Darul Ehsan Malaysia

M.F.M. Yusof

School of Health Sciences

Health Campus

Universiti Sains Malaysia

16150 Kubang Kerian, Kelantan Darul Naim

Malaysia
*Corresponding author; email: racd919@gmail.com

Received: 25 September 2017

Accepted: 21 January 2018 